\title{
EVALUATION AND IMPROVEMENT OF DRAINAGE PERFORMANCE IN GEDONGTATAAN, LAMPUNG USING DUFLOW MODELING STU- DIO
}

\author{
Anna Mariana Situngkir \\ Badan Lingkungan Hidup Kabupaten Pesawaran Provinsi Lampung, Jalan Tauldan - Sukaraja I, Gedongtataan, \\ Lampung, Indonesia 35371, Telp/fax: (0729)95046 - annasitungkir1@gmail.com
}

\begin{abstract}
Gedongtataan is the capital city of Pesawaran Regency which some areas such as roads and settlements always experience flooding annually with maximum inundation depth $0.5 \mathrm{~m}$. Flooding leads to road congestion. This study had objectives to evaluate the performance of existing drainage network and to discuss the improvement options of drainage system to cope the flood. The performance of existing drainage network and the improvement options were evaluated using Duflow Modelling Studio since the network is an open channel and the modeling is easy to operate. The simulation of Duflow Modelling Studio shows that the existing drainage network has less performance since some areas were flooded. The cause of flood was insufficient drainage capacity due to less dimension and poor drainage condition due to solid waste and grass weed in the drainage canals. Three options were developed to prevent the flood, Option 1 cleaning canals from solid waste and grass weed, Option 2 dyke construction and canal widening, and Option 3 resizing canals, a combination of dredging and widening canals. The best improvement option to prevent the flood based on the benefits and drawbacks of each options was Option 3 resizing canals since it is long term solution and not costly to prevent the flood.
\end{abstract}

Keywords: Duflow Modeling Studio, Flood, Flood Improvement Option, Gedongtataan, Urban Drainage

(Diterima: 04-04-2016; Disetujui: 27-07-2016)

\section{Introduction}

Gedongtataan is situated at Southern part of Lampung. Gedongtataan is the capital city of Pesawaran Regency and covers area 9,700 $\mathrm{Ha}$, which is $8.27 \%$ from the whole area of the regency. (Figure 1).
The population of Gedongtataan is 92,630 inhabitants (2014) with population growth is $1.09 \%$ per year and population density 950 people $/ \mathrm{km}^{2}$ (Statistics Board of Pesawaran, 2014).

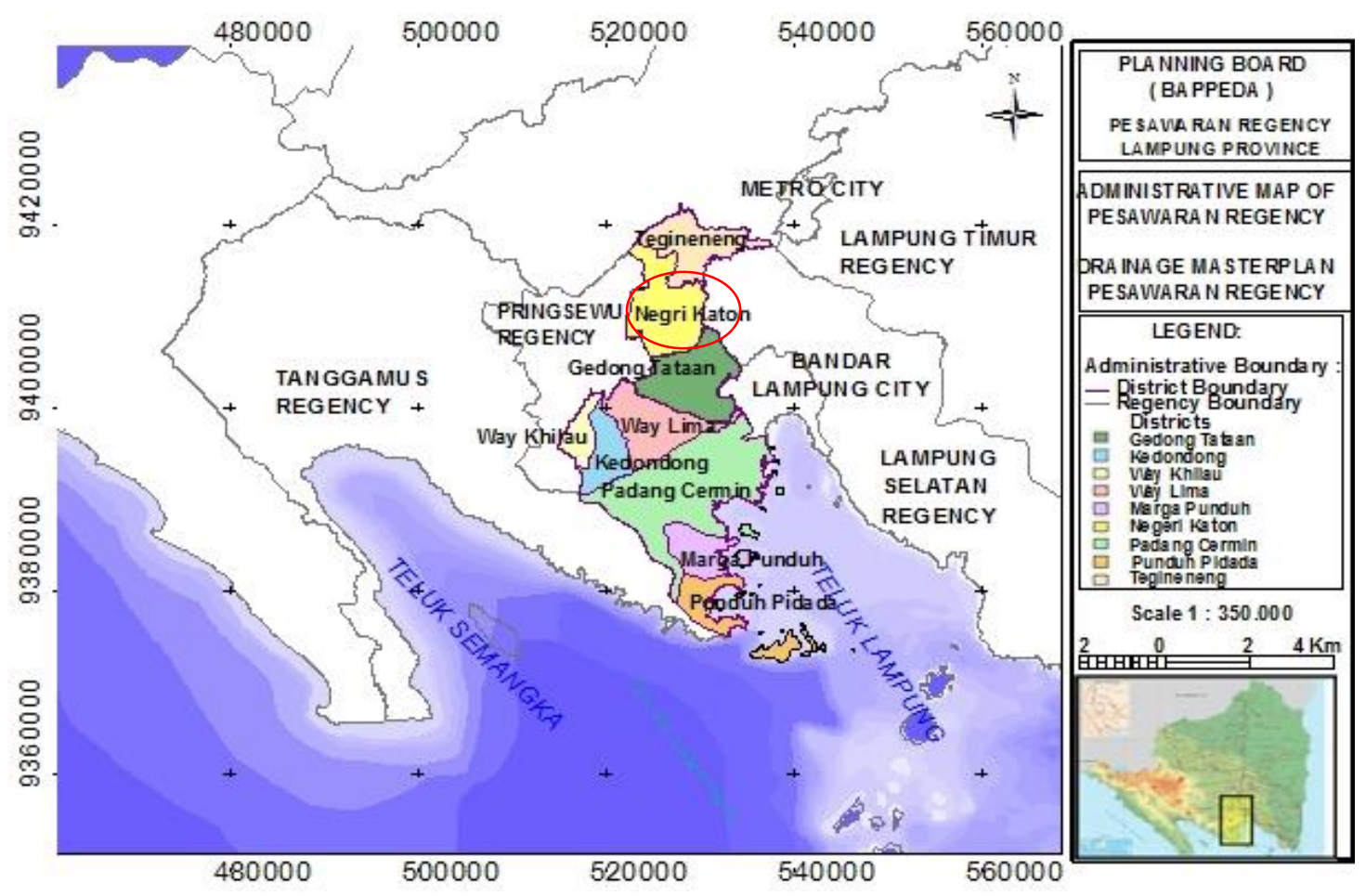

Figure 1 Location of Gedongtataan

Source: Urban Development Planning Board of Pesawaran Regency (2013) 
Drainage is an important infrastructure in urban area because of its functions to reduce the excess water which comes from rainfall, seepage, and waste water and to flow the water to river, sea, or lake (Suripin, 2004).

The city is under developing but the drainage system is not developed well. According to Butler and Davies (2004), development can increase impermeable land and will influence water flows in nature. Furthermore, during development, people use to change the land use. People develop new settlement areas and commercial areas. These activities would cause flood if sufficient drainages are not provided.
Therefore, it can be said that flood is caused by human activities such as development and urbanization (Yuksek et al., 2013).

Drainage system in Gedongtataan flow water to Way Semah River which crosses the city. This river has dendritic pattern. Drainage system is not developed well. The evidence of unwell developed drainage are that the drainages were often clogged by solid waste thrown away by the inhabitants, silting in drainages,grass weed grew inside the canals, lack maintenance of drainages, and lack of drainage along the road. (Figure 2) Therefore, the city faces flooding annually.

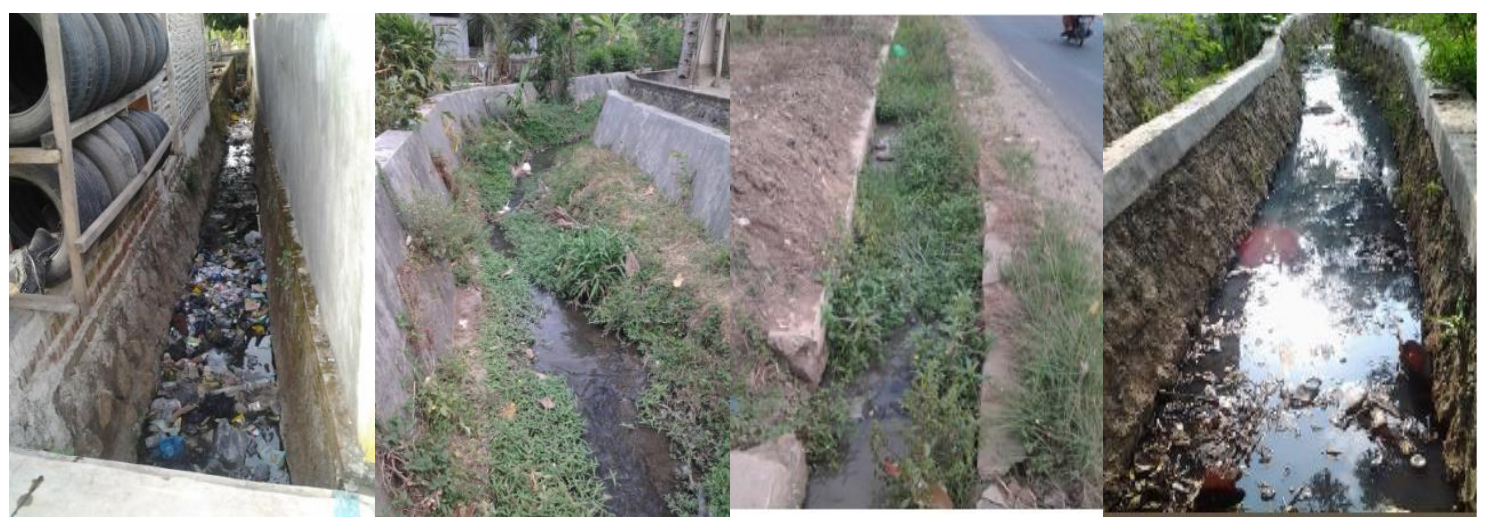

Figure 2. Drainage Canals Condition at Gedongtataan Source: Field Observation (2015)

On the hand, annual flood impacts on road congestion, which becomes an obstacle for people's activity. People come late to office and their trip to Bandar Lampung City is disrupted. The non-integrated and inadequate drainage along the road also triggers flood. When heavy rain comes, it causes overflow of the canals. Hence, the flood problem in Gedongtataan should be overcome.

This research had two objectives, which were to evaluate the performance of existing drainage system at Gedongtataan, and to discuss the improvement options of drainage system to prevent the flood.

\section{Methodology}

This study consisted of some steps, those were: collecting data, analyzing rainfall data, and Duflow Modelling Studio (DMS) consisted of inputting data, DMS simulation, improvement options, and analysing options. General flowchart of research methodology is presented in Figure 3.

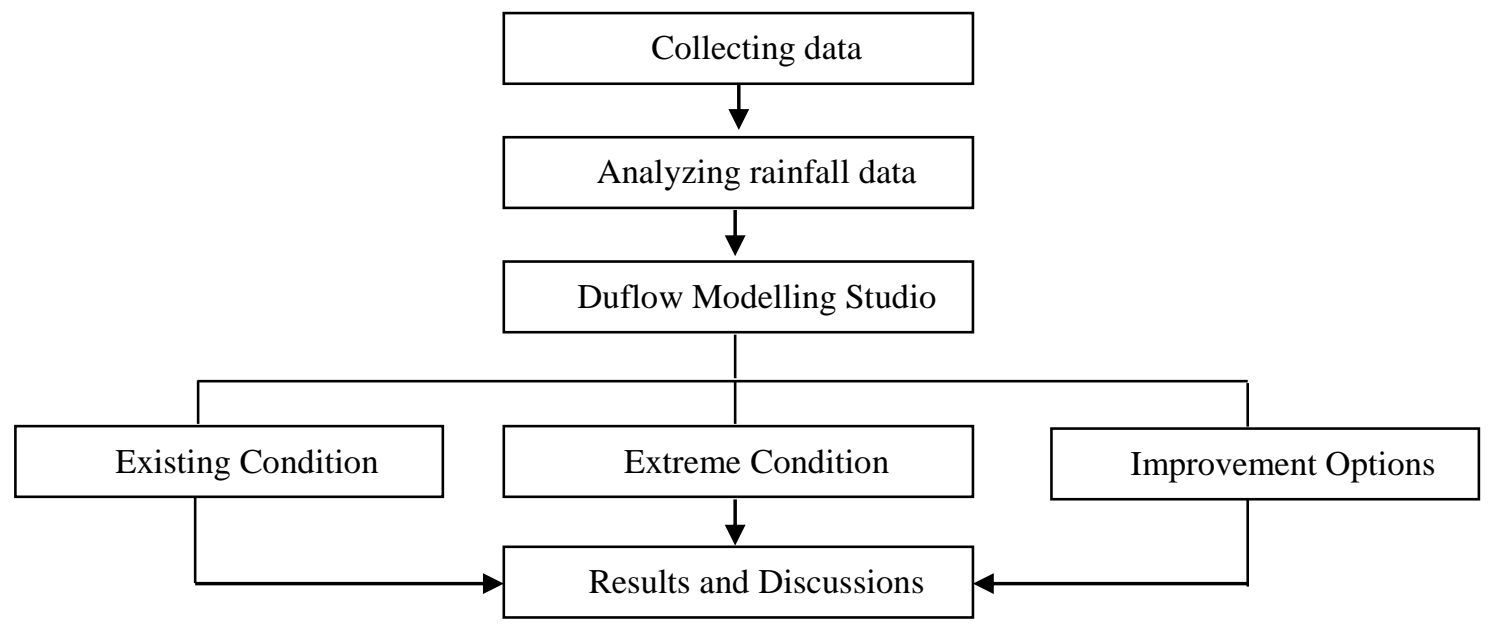

Figure 3. The Flowchart of Research Methodology 


\subsection{Collecting data}

Data required for this study was cross section of rivers and drainages, discharge of river, condition of rivers and drainages, rainfall, and water level of the river.

\subsection{Analyzing rainfall data}

Analyzing rainfall data from Meteorology, Climatology, and Geophysics Agency of Tegineneng in Way Semah Observation Station is needed to obtain rainfall causing the flood in existing condition and to predict extreme rainfall with return period 50 years. Rainfall with return period 50 years chose because drainage in Gedongtataan is categorized as medium risk urban drainage based on area and risk (Ponce, 1989). Rainfall was analyzed using Gumbel Type I Distribution because it has the smallest maximum difference (Ningsih, 2014). The equation of Gumbel Type I distribution based on Patra (2008) is:

$$
\begin{gathered}
X=X_{a}+\left(K_{T} x S\right) \\
K_{T}=\frac{Y_{T}-Y_{n}}{S_{n}} \\
Y_{T}=-\ln \left\{-\ln \left(\frac{T_{Y}-1}{T_{Y}}\right)\right\}
\end{gathered}
$$

Where:

$$
\begin{array}{ll}
\mathrm{X} & =\text { Design rainfall }(\mathrm{mm}) \\
\mathrm{X}_{\mathrm{a}} & =\text { Average rainfall }(\mathrm{mm}) \\
\mathrm{K}_{\mathrm{T}} & =\text { Frequency factor } \\
\mathrm{S} & =\text { Standard deviation } \\
\mathrm{Y}_{\mathrm{T}} & =\text { Coefficient of Gumbel Distribution } \\
\mathrm{Y}_{\mathrm{n}} & =\text { Reduced mean from Gumbel } \\
\mathrm{S}_{\mathrm{n}} & =\text { Reduced standard deviation from Gumbel } \\
\mathrm{n} & =\text { Number of data }
\end{array}
$$

Design rainfall obtained from calculation would be used to figure the relation between intensity, duration, and frequency of rainfall through Intensity-DurationFrequency (IDF) curve using Van Breen's Equation.

$$
I=\frac{54 R_{24}+0.007 R_{24}^{2}}{t+0.31 R_{24}}
$$

Where:

I = Rainfall intensity ( $\mathrm{mm} /$ hour)

$\mathrm{T}=$ Duration (hour)

$\mathrm{R}_{24}=$ Maximum daily rainfall $(\mathrm{mm})$

\subsection{Duflow Modelling Processing}

This step covered inputting data, making rivers and drainages schematization, calibrating model, option development, simulating result, and analyzing result.

DMS was used in this study due to some reasons, for example:
a. Rivers and drainage canals are open channels
b. The flow can be assumed as an unsteady flow
c. The floor slope is relatively small and stable

d. The stream is suggested as straight line

e. The fluid is incompressible

f. Accelerations in vertical direction are ignored (STOWA and Systems, 2004).

Moreover, it is difficult to measure peak discharge of the river when rainy season because the measurement was done on dry season therefore the peak discharge would be calculated using RAM (Rainfall Runoff) which is a part of DMS. RAM would calculate the surface runoff based on input precipitation and surface area which is influenced by paved surface, unpaved surface, and open water (Madamombe, 2010). DMS has also benefits like one-dimensional model, simple, easy to operate, and user friendly.

In DMS, the schematization will illustrate rivers and drainage canals network which were indicated by some sections and some nodes (Clemmens et al., 1993). One section consisted of two nodes with particular distance. Each section defined longitudinal section of rivers and canals which has different distance and cross section. In the schematization, the network can be combined with hydraulics infrastructures such as gate, weir, dikes, and culvert. In this study, the network would be combined with a weir and culverts that were found in the field.

In hydrology, DMS has been employed for various objectives such as performing operated hydraulics infrastructures, assessing the performance of irrigation and drainage system, and performing the effect of water management systems on specific area. Moreover, according to Badilla (2008), DMS was used as early warning system for alarming flood.

DMS will present the performance of drainage in existing condition, extreme condition, and three improvement options. Three options to be proposed to prevent the flood in Gedongtataan were Option 1 cleaning canals from solid waste and grass weed, Option 2 dyke construction and widening canals, and Option 3 resizing canals, which is combination between dredging and widening canals.

Option 1 was done to improve canals' roughness by changing Chezy Coefficient from $30 \mathrm{~m}^{2} / \mathrm{s}$ (lack maintenance) to $45 \mathrm{~m}^{2} / \mathrm{s}$ (good maintenance) and deepening canals' floor are $0.5 \mathrm{~m}$ from existing depth to improve the canals' capacity. Option 2 was done by constructing dykes with height between $0.5 \mathrm{~m}$ and $0.7 \mathrm{~m}$ to increase surface level and widening canals between $0.5 \mathrm{~m}$ and $1.0 \mathrm{~m}$ from existing width to increase the perimeter area of canals. Option 3 was done by deepening between $0.5 \mathrm{~m}$ and $0.7 \mathrm{~m}$ from existing depth and widening between $0.5 \mathrm{~m}$ and 1.0 $\mathrm{m}$ from existing width to improve the capacity of the canals.

The best option will be decided based on matrix of the benefits and drawbacks of each option. The option which has more benefits than drawbacks will be decided as the best option. 


\section{Results and Discussions}

\subsection{Rainfall Analysis}

\subsubsection{Existing Rainfall}

Based on daily rainfall data period 2002 - 2014, the maximum daily rainfall is presented in Figure 4. It can be seen that the highest daily rainfall was 120 $\mathrm{mm}$ /day occurred on 2004 and the lowest rainfall was $70 \mathrm{~mm} /$ day on 2007. The highest rainfall would be input into schematization.

\subsubsection{Extreme Rainfall}

The design rainfall for extreme condition was resulted through calculation using Gumbel Distribution which can be seen in Table 1 . While, the relationship between Rainfall Intensity, Duration, and Frequency is shown in IDF Curve in Figure 5

Table 1. Design Rainfall for Return Period

\begin{tabular}{cc}
\hline $\begin{array}{c}\text { Return Period } \\
\text { (years) }\end{array}$ & Design Rainfall (mm) \\
\hline 2 & 91 \\
\hline 5 & 108 \\
\hline 10 & 119 \\
\hline 20 & 130 \\
\hline 25 & 133 \\
\hline 50 & 144 \\
\hline 100 & 155 \\
\hline
\end{tabular}

From the graph, it can be concluded that rainfall intensity is high when rainfall duration is short. Also, longer rainfall return period, rarer rainfall occurrence.

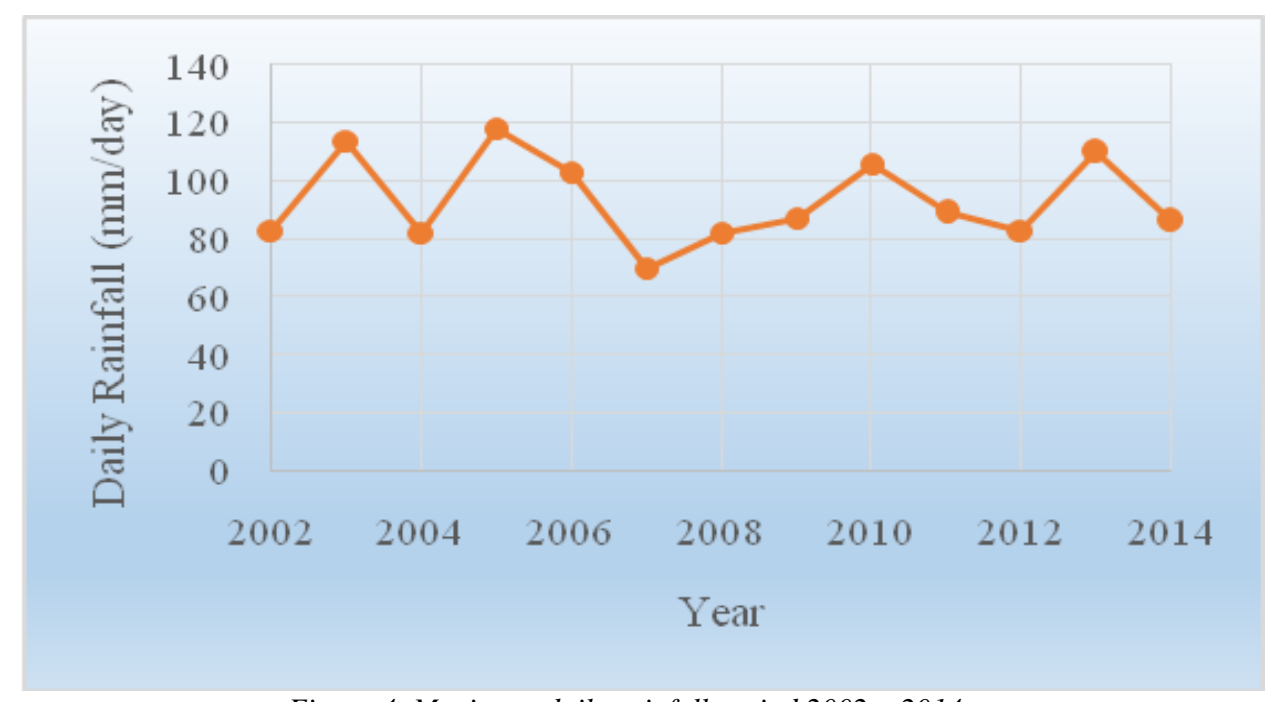

Figure 4. Maximum daily rainfall period 2002 - 2014

Source Data: Meteorology, Climatology, and Geophysics Agency of Tegineneng in Way Semah Observation Station

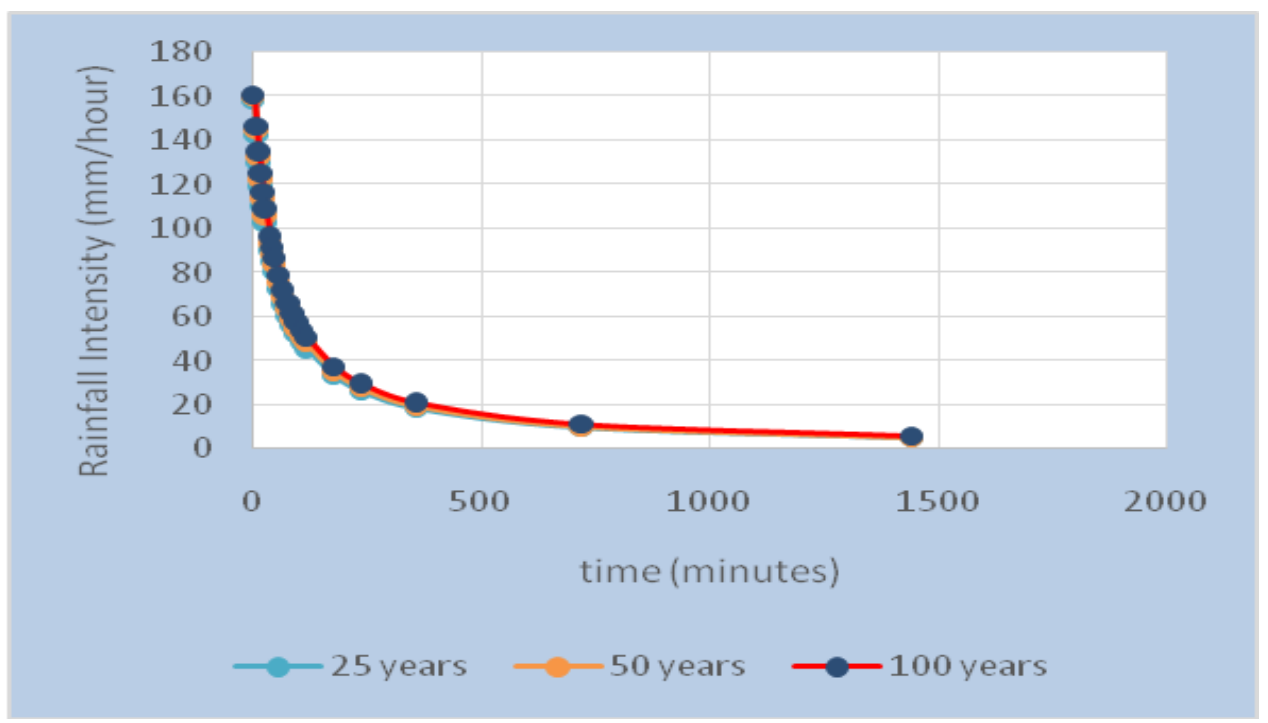

Figure 5. IDF Curve using Van Breen's Formula 


\subsection{Modelling Schematization}

There are three rivers and two drainage canals schematizing in this study. The rivers are Way Semah, Way Gading, and Kebagusan. The drainage canals are Kutoarjo, Bagelen, and Sukaraja Drain. The schematization of the rivers and drainage canals is illustrated in Figure 6.

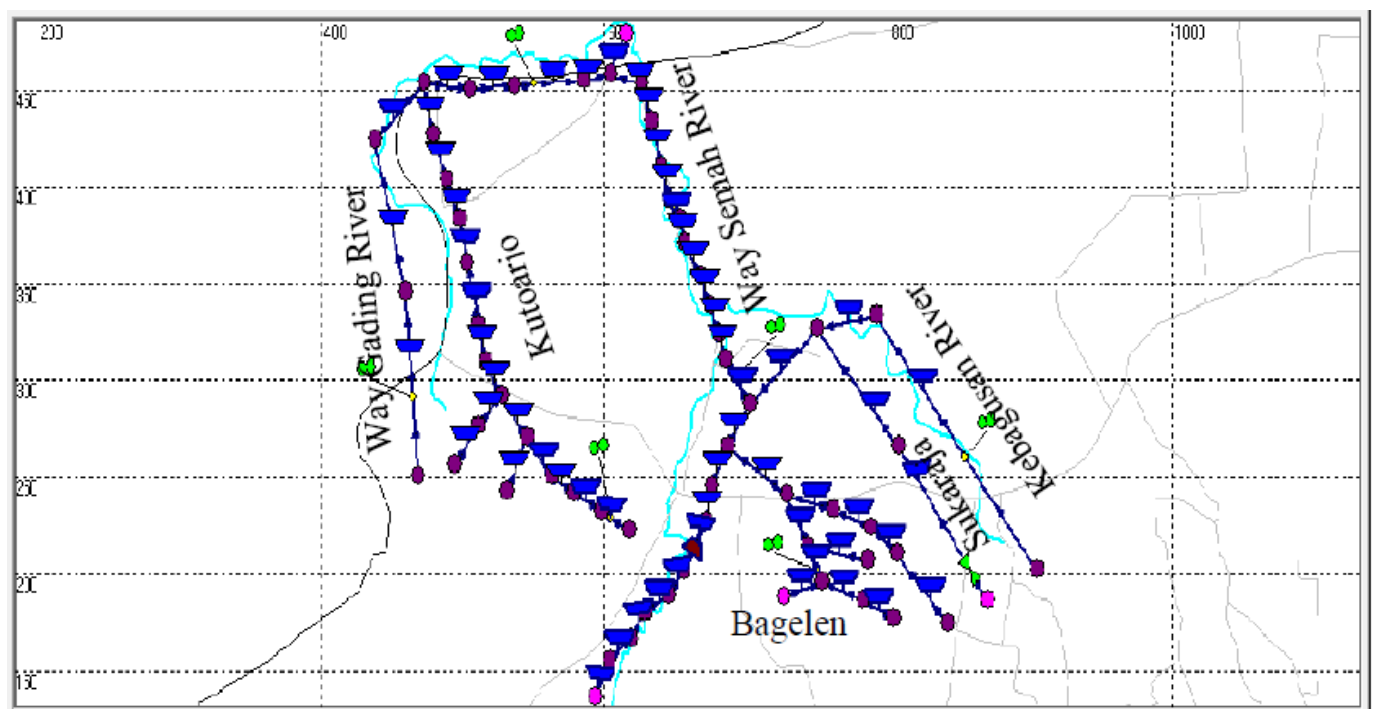

Figure 6. Rivers and Canals Schematization in DMS

\subsubsection{Input Data}

Data would be input to DMS for existing condition are as follows:
a. Upstream boundary: discharge of Way Semah River $\left(=0.3 \mathrm{~m}^{3} / \mathrm{s}\right)$
b. Downstream boundary: water level at down- stream of Way Semah River $(=110.3$ $\mathrm{mm}+\mathrm{MSL}$ )
c. Rainfall : $118 \mathrm{~mm} /$ day
d. Evaporation: $4.2 \mathrm{~mm} /$ day
e. Canal roughness (Chezy Coefficient: 30 $\mathrm{m}^{1 / 2} / \mathrm{s}$ ) because of lack of maintenance
f. Paved area: $35 \%$
g. Unpaved area: $55 \%$
h. Open water: $10 \%$
i. Greenhouse and sewer: $0 \%$

Data for existing condition would be used for extreme condition, except:
a. Rainfall: $28 \mathrm{~mm} /$ hour or $672 \mathrm{~mm} /$ day (de- sign rainfall with return period 50 years)
b. Paved area: $60 \%$, due to land use change
c. Unpaved area: $30 \%$
d. Open water: $10 \%$

\subsubsection{Modelling Calibration}

Calibration was done at two points, which were at middle stream and downstream of Way Semah River shown in Figure 7. The results of calibration at both points are shown in Figure 8 and Figure 9.

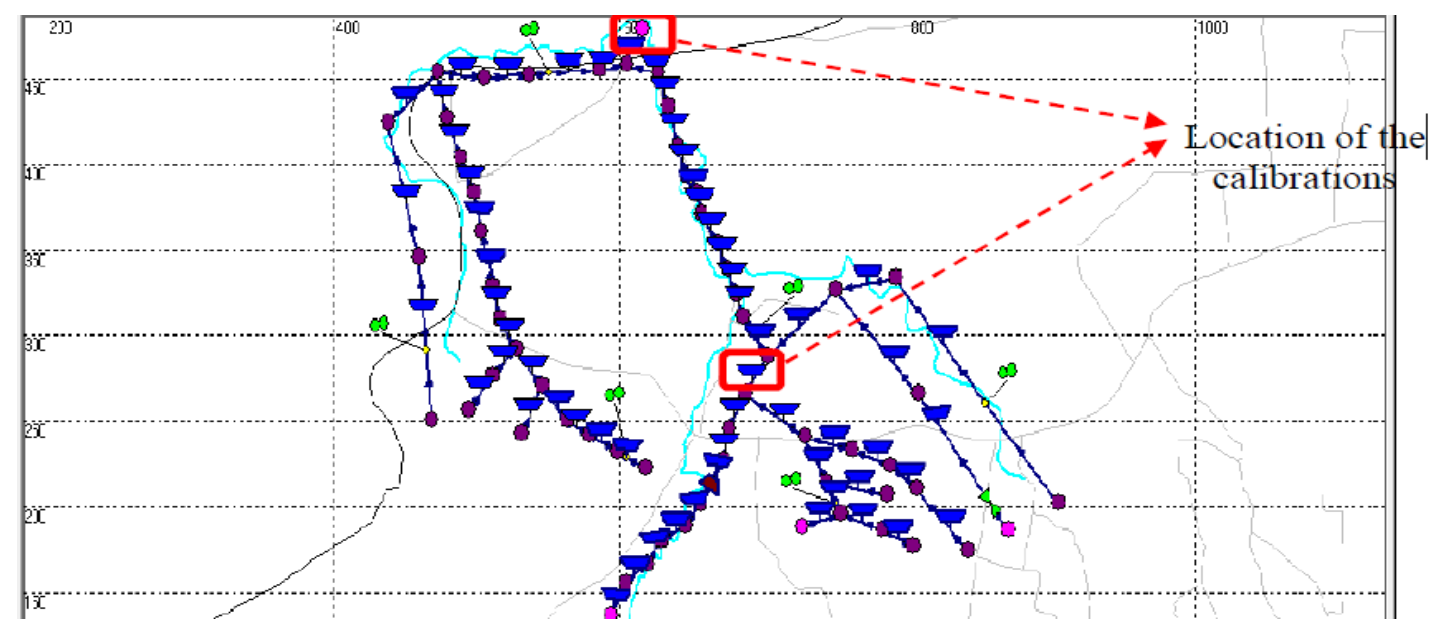

Figure 7. Location of Calibration 


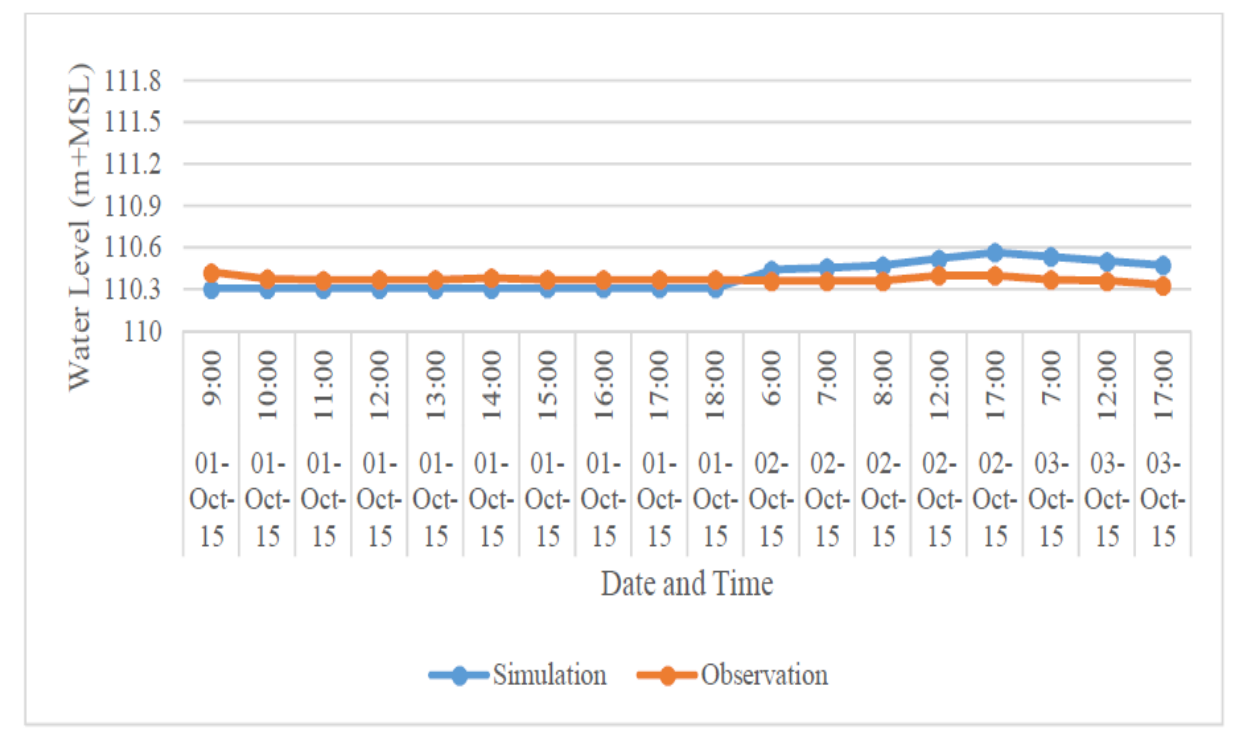

Figure 8. Result of Calibration at Downstream

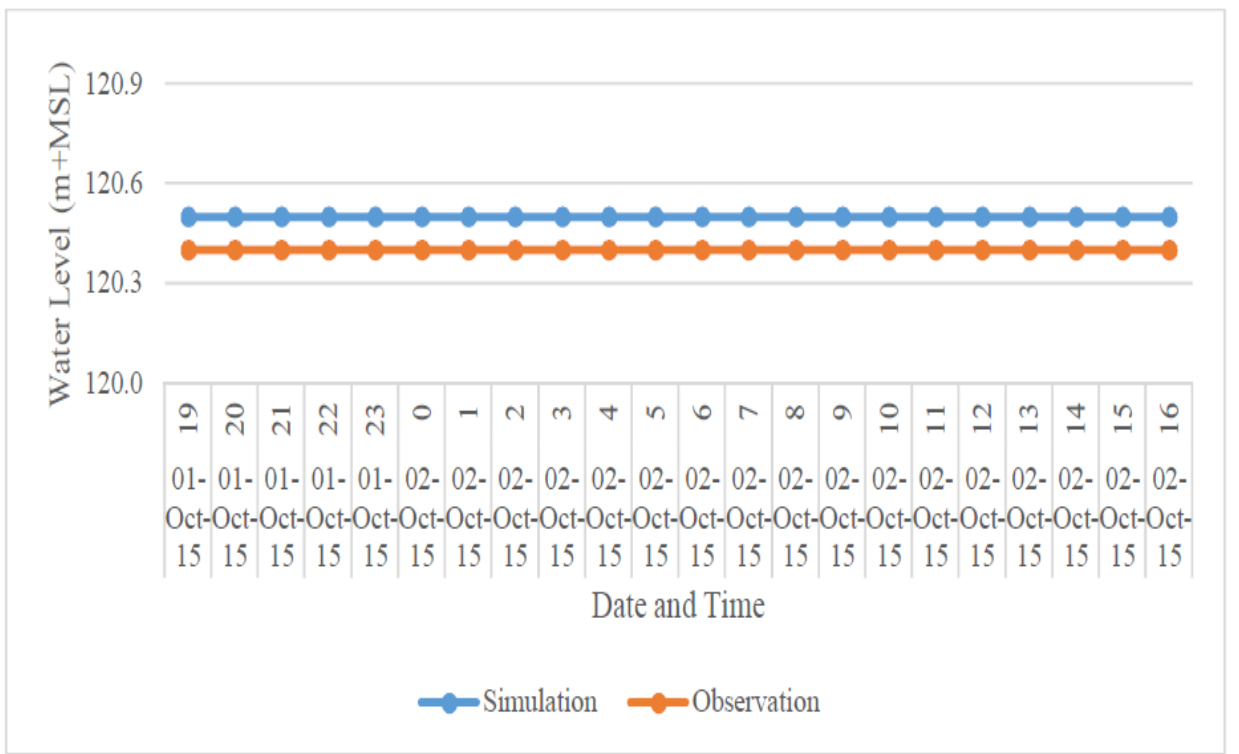

Figure 9. Result of Calibration at Middle Stream

From both figures, it can be seen that the difference between measured water level and Duflow water level was between $0.05 \mathrm{~m}$ until $0.2 \mathrm{~m}$ so the water level resulted by Duflow was close to the water level got from measurement. Therefore, the model can be developed further for other options.

\subsection{Result of Modeling Simulation}

\subsubsection{Existing Condition}

The simulation of DMS shows that some areas face inundation which can be seen in Table 2 .

\begin{tabular}{cc} 
Table 2. Inundated Sections in Existing Condition \\
\hline $\begin{array}{c}\text { Section } \\
\text { Number }\end{array}$ & $\begin{array}{c}\text { Inundation Depth } \\
(\mathbf{m m})\end{array}$ \\
\hline 00 & 0.5 \\
\hline 31 & 0.2 \\
\hline 48 & 0.1 \\
\hline 16 & 0.3 \\
\hline 19 & 0.2 \\
\hline
\end{tabular}

The result of DMS simulation is presented in Figure 10. The inundation occurred is shown by the red line. 


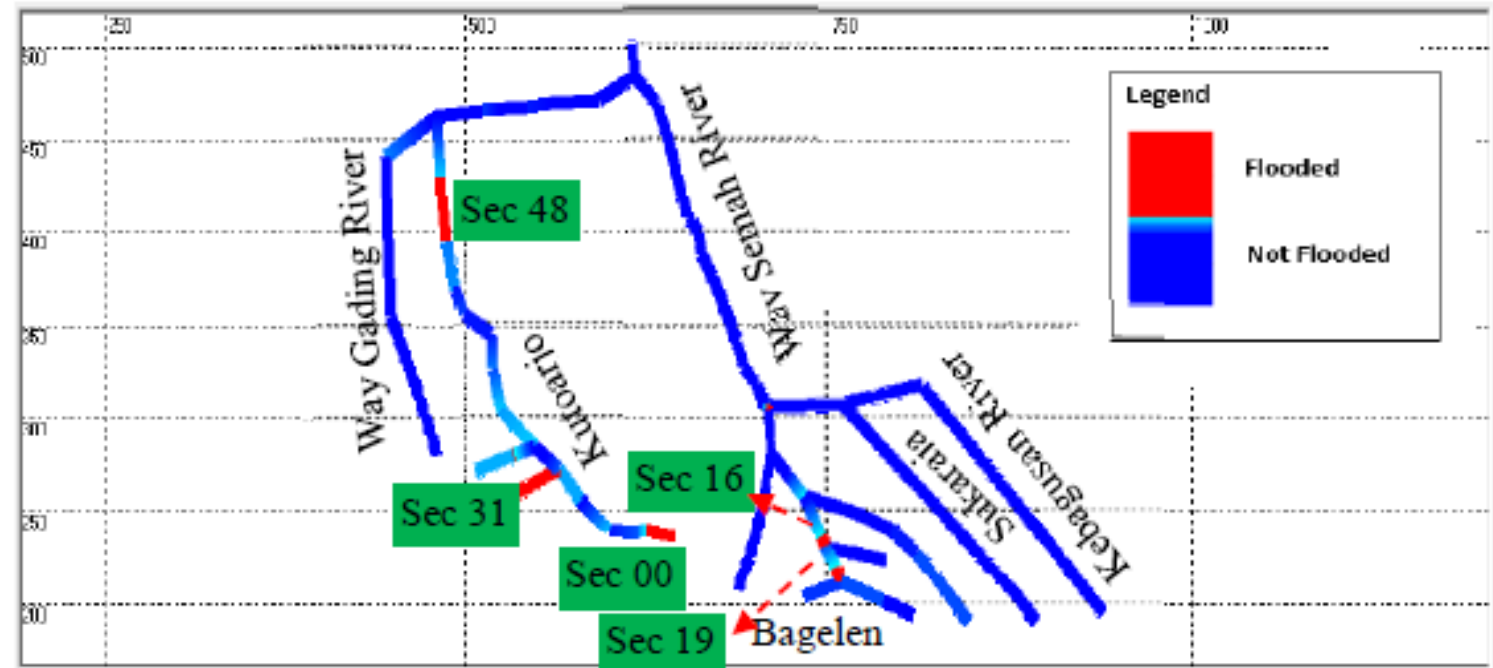

Figure 10. Result of Simulation for Existing Condition

\subsubsection{Extreme Condition}

DMS shows that there were more section inundated and the inundation depth in extreme condition more increase which is shown in Table 3. The inundated sections are shown by red line in Figure 11

Table 3. Inundated Sections in Extreme Condition

\begin{tabular}{ccc}
\hline $\begin{array}{c}\text { Section } \\
\text { Number }\end{array}$ & $\begin{array}{c}\text { Inundation Depth (mm) } \\
\text { dition }\end{array}$ & $\begin{array}{c}\text { Extreme Con- } \\
\text { dition }\end{array}$ \\
\hline 00 & 0.5 & 1.1 \\
\hline 31 & 0.2 & 0.7 \\
\hline 48 & 0.1 & 0.5 \\
\hline 16 & 0.3 & 0.6 \\
\hline 19 & 0.2 & 0.6 \\
\hline 23 & 0 & 0.5 \\
\hline 29 & 0 & 0.7 \\
\hline 36 & 0 & 0.5 \\
\hline
\end{tabular}

\subsubsection{Improvement Options}

The proposed improvement options to prevent the flood in both existing and extreme condition are:
a. Option 1 cleaning canals
b. Option 2 dyke construction and widening canals
c. Option 3 resizing canals (combination of deepening and widening)

\section{Option 1 Cleaning Canals}

Option 1 is to prevent the inundated sections by cleaning canals and rivers from solid waste, grass weed, and silting that can clog water flow which causes water flow slowly therefore solid waste, grass weed, and silting inside the canals can lead to flood risk. Option 1 was done to improve canals' roughness by changing Chezy Coefficient from $30 \mathrm{~m}^{2} / \mathrm{s}$ (lack maintenance) to $45 \mathrm{~m}^{2} / \mathrm{s}$ (good maintenance) and deepening canals' floor are $0.5 \mathrm{~m}$ from existing depth to improve the canals' capacity. The result of Option 1 is provided in Figure 12. It can be seen that inundated sections are reduced shown by red line in which only two inundated sections of the whole area.

\section{Option 2 Dyke Construction and Widening Canal}

In order to prevent the flood, dykes are built at inundated sections with height between $0.5 \mathrm{~m}$ and 0.7 $\mathrm{m}$ and followed by widening canals between $0.5 \mathrm{~m}$ and $1.0 \mathrm{~m}$ from existing width. Dykes are constructed to increase surface level and canals are widened to increase the perimeter area of canals. This combination will increase canals' capacity. The result of DMS simulation for Option 2 is presented in Figure 13. From that figure, it can be seen that there is no inundated sections. 


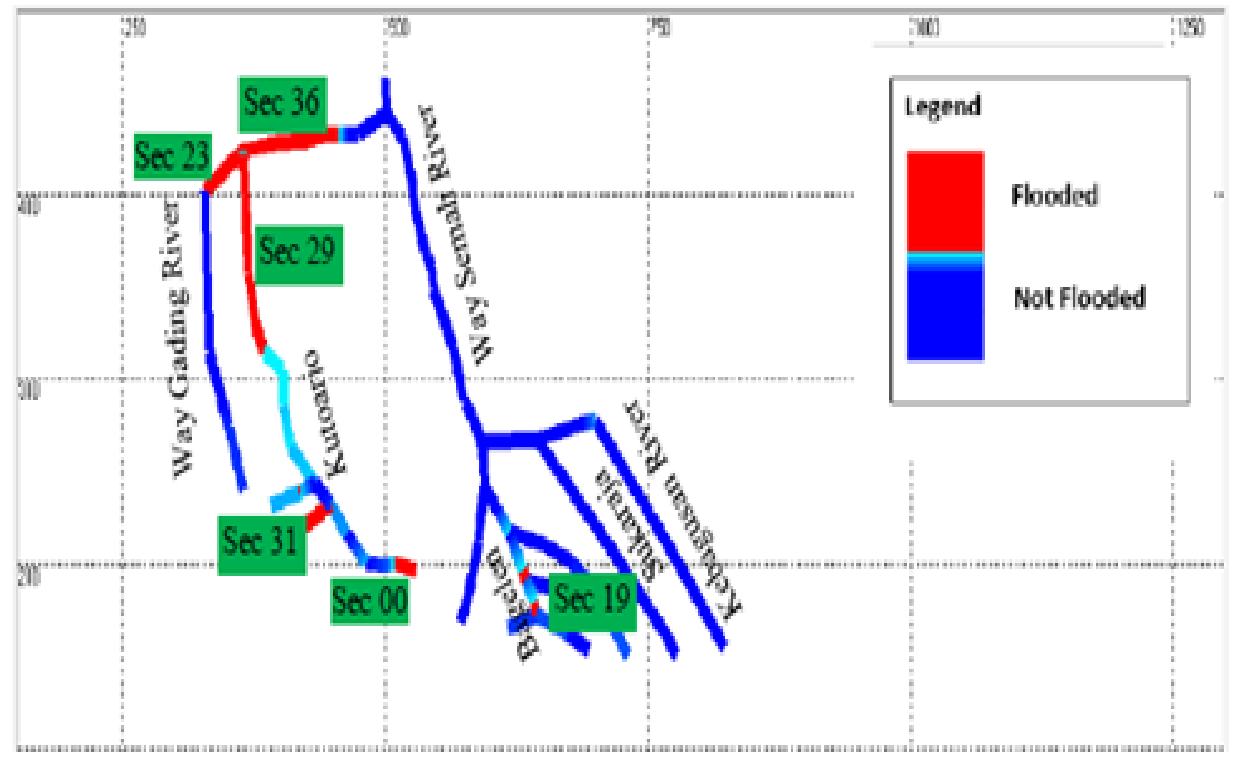

Figure 11. Result of Simulation for Extreme Condition

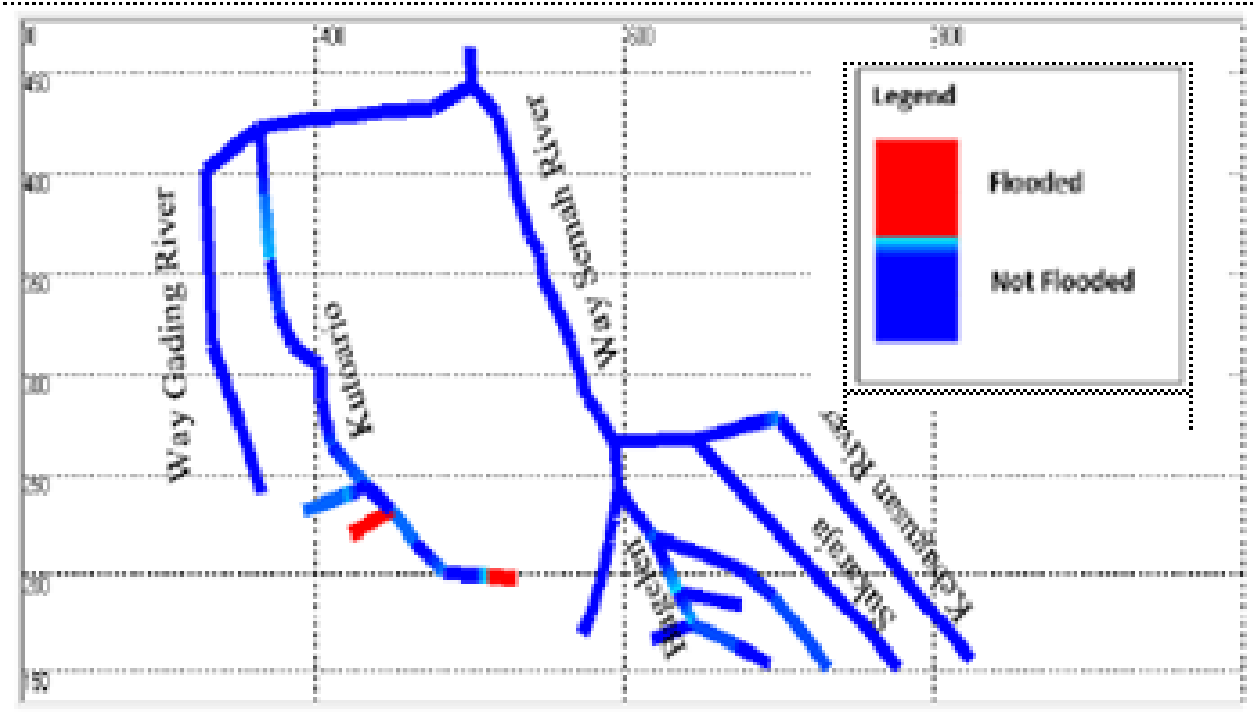

Figure 12. Result ofDMS Simulation of Option 1

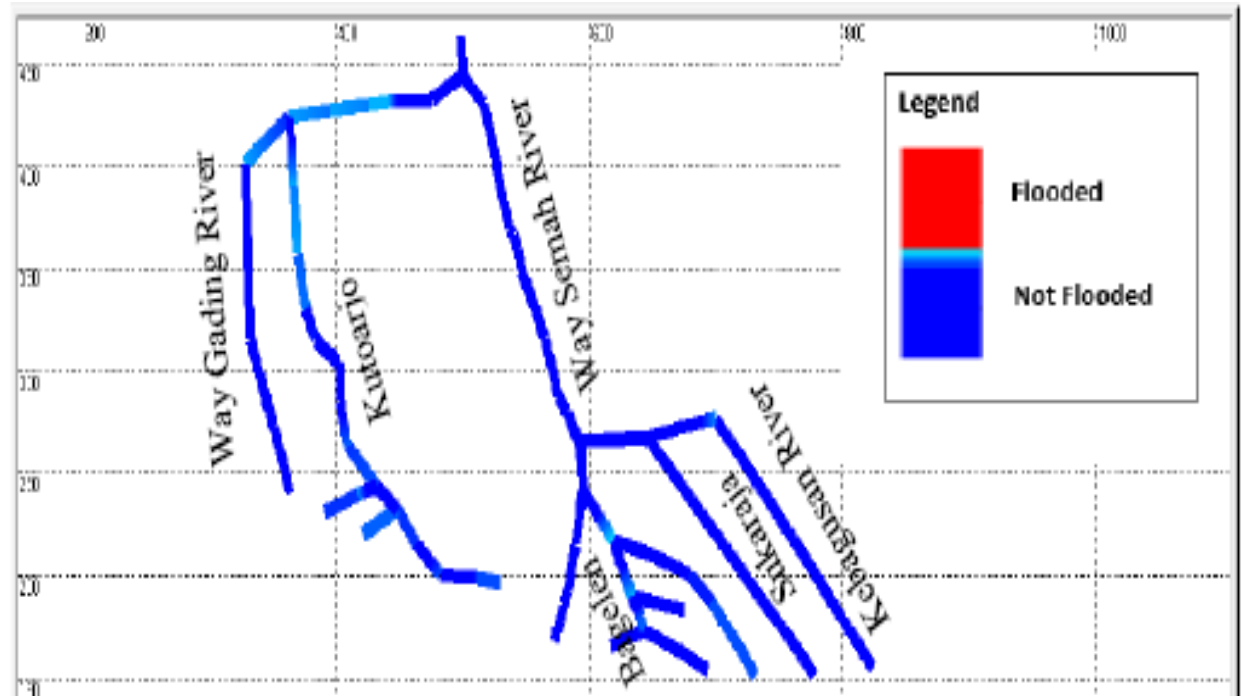

Figure 13. Result of DMS Simulation of Option 2 


\section{Option 3 Resizing Canals}

Option 3 Resizing canals, a combination between widening and deepening canals. This option is taken in order to enlarge the perimeter area so the capacity of the canals will be improved. The canals at inundated sections are deepened between $0.5 \mathrm{~m}$ from existing depth and $0.7 \mathrm{~m}$ and widened between $0.5 \mathrm{~m}$ and $1.0 \mathrm{~m}$ from existing width. The result of deepening and widening canals is illustrated in Figure 14. It can be seen that resizing canals can prevent flood because the perimeter area of canals increases so the discharge in canals becomes higher.

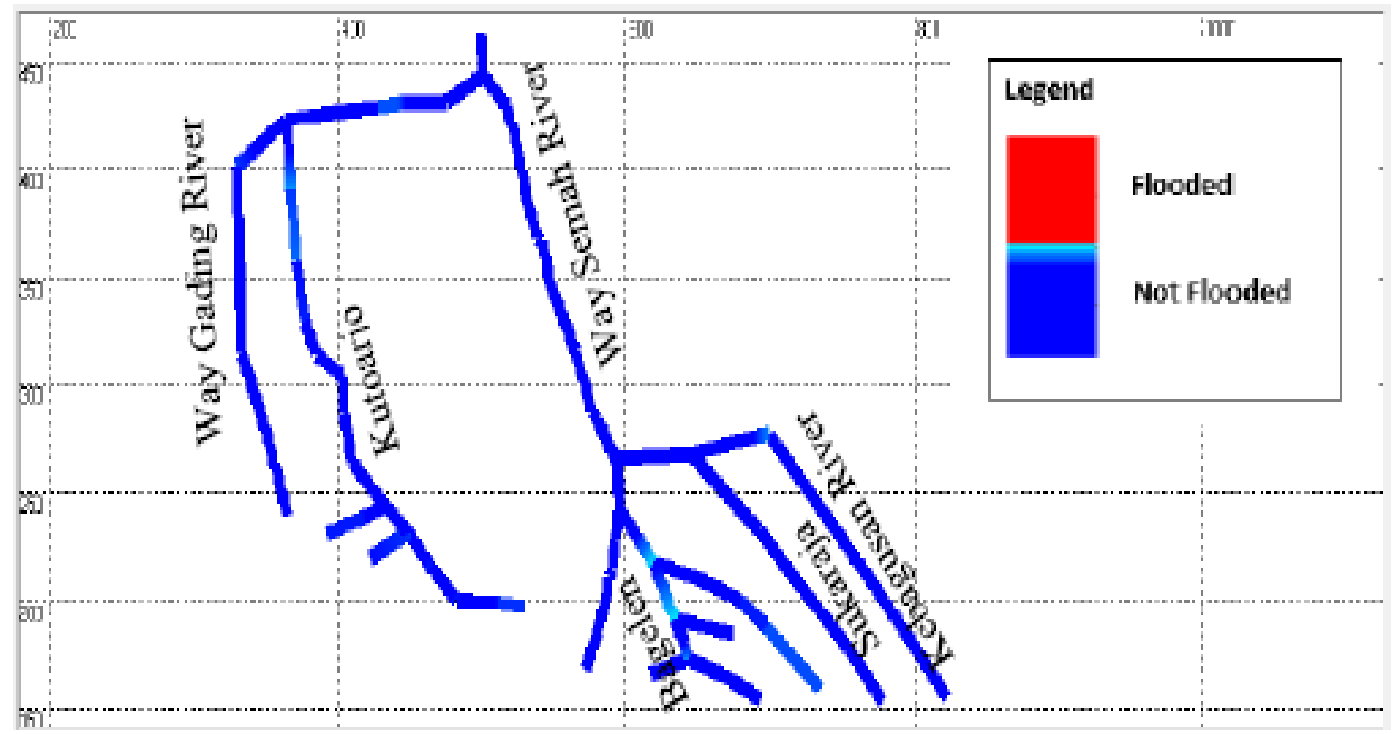

Figure 14. Result of DMS Simulation of Option 3

\subsection{The Cause of Flood}

Flood in Gedongtataan was caused by drainage canals in some sections have less dimension which is shown in Table 4. Moreover, based on field survey, there were solid waste, grass weed, and silting inside the canals.

Table 4. Dimensions and Conditions of Inundated Sections

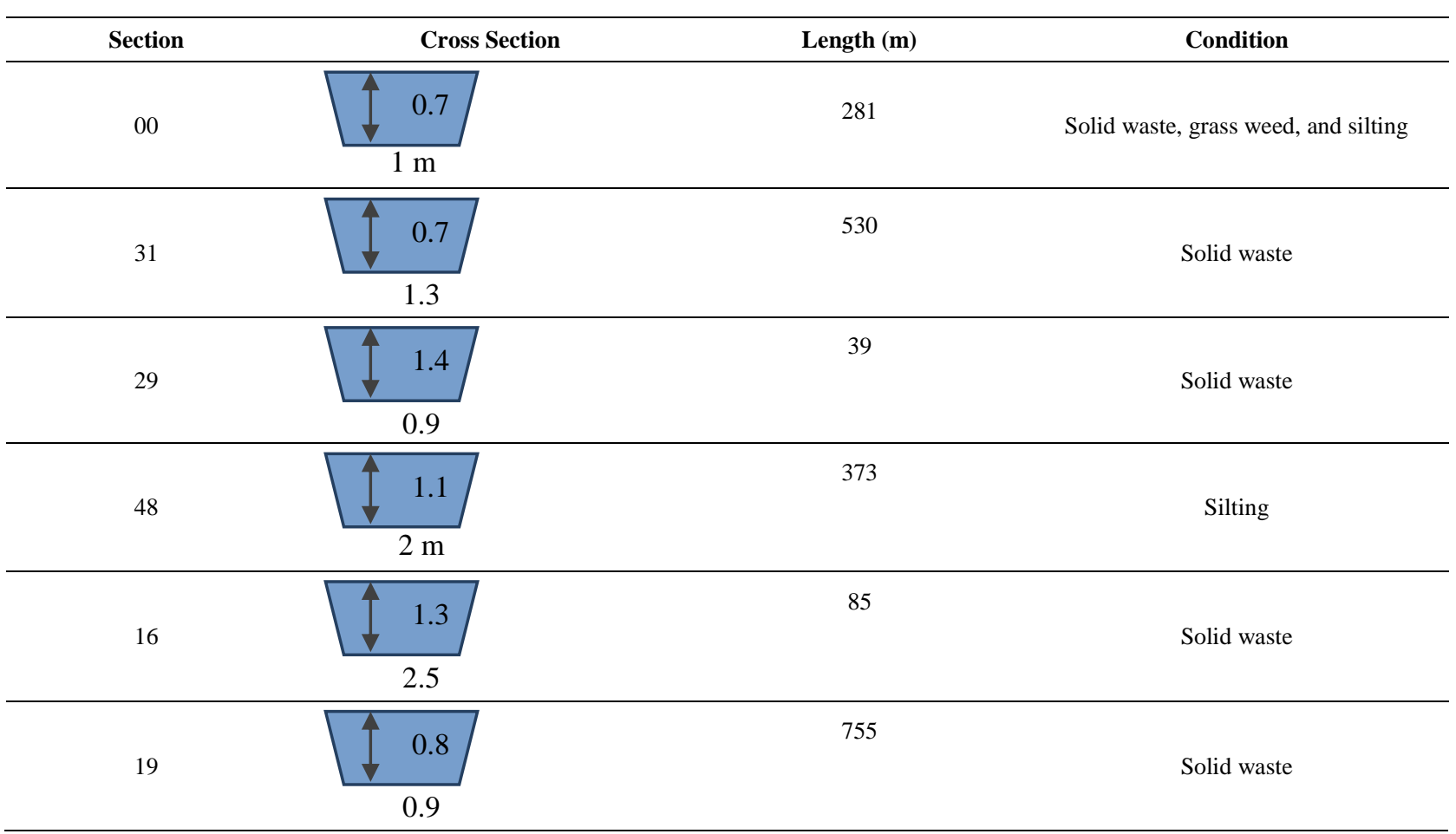




\subsection{Best Option}

The best improvement option was evaluated based on the benefits and drawbacks of each option which presented in the matrix in Table 5.

Therefore, the best option can be taken to prevent the flood from Table 5 is Option 3 Resizing Canals (Widening and Deepening Canals).

Beside technical aspects which have been discussed, flood can be mitigated by participating society. The society should be trained in some small groups to develop their awareness and they should be responsible to keep the canals and rivers in clean condition. Social participatory is important to develop their belonging and responsibility to the rivers, drainage canals, and public infrastructures.

Furthermore, the land use change during the development which cannot be avoided should be controlled by government and the government should provide a good spatial planning. Government should include drainage building during development and keep the paved area maximum $60 \%$ and open green space at least $30 \%$ based on Law No. 26/2007 about Spatial Planning.

Table 5. Matrix of Benefits and Drawbacks

\begin{tabular}{|c|c|c|}
\hline Option & Benefits & Drawbacks \\
\hline 1. Cleaning canals & $\begin{array}{l}\text { - It can reduce the flood only until } 0.4 \\
\text { m. } \\
\text { - No need to invest new infrastructure. } \\
\text { - Society can do divided into some } \\
\text { groups to do cleaning in turn for cer- } \\
\text { tain period. }\end{array}$ & $\begin{array}{l}\text { - There are still inundated sections. } \\
\text { - Short term prevention because the } \\
\text { solid waste and grass weed will be } \\
\text { there again. } \\
\text { - Might need to prepare regular budget } \\
\text { for a person in task to do regular } \\
\text { cleaning. } \\
\text { - Citizens' awareness should be im- } \\
\text { proved. } \\
\text { - It needs cooperation between govern- } \\
\text { ment and citizens }\end{array}$ \\
\hline 2. Dyke construction and canal widening & $\begin{array}{l}\text { - There are no inundated sections. } \\
\text { - It can be a long term solution. } \\
\text { - It can be utilized for pedestrians. } \\
\text { - It is nice to see the real development } \\
\text { for citizens. }\end{array}$ & $\begin{array}{l}\text { - It is costly to build dyke. } \\
\text { - It might be breach because of over- } \\
\text { topping. } \\
\text { - It needs more space for widening } \\
\text { canals. }\end{array}$ \\
\hline 3. Resizing canals & $\begin{array}{l}\text { - There are no inundated sections. } \\
\text { - It can be a long term mitigation. } \\
\text { - The dredged soil can be re-used. } \\
\text { - It is not costly compared to dyke con- } \\
\text { struction. }\end{array}$ & $\begin{array}{l}\text { - It needs to consider how to transport } \\
\text { dredged soil. } \\
\text { - The canal deepening should consider } \\
\text { slope stability. }\end{array}$ \\
\hline
\end{tabular}

\section{Conclusions}

This study resulted in two conclusions. First, the existing drainage network at Gedongtataan has less performance which was proven that some sections were flooded. The cause of flood was insufficient drainage capacity due to less dimension and poor condition of drainage caused by solid waste, grass weed, and silting.

Second, there were three proposed improvements to be done to prevent the flood; Option 1 cleaning canals, Option 2 dyke construction, and Option 3 resizing canals. Based on advantages and disadvantages, the best improvement option was Option 3 resizing canals, which is a combination between deepening and widening because the option can overcome the flood optimally, it can be a long term solution, and not costly. Option 1 is a short term solution, it should be done regularly, and it is influenced by society's behavior and awareness. Option 2 dyke construction and widening canals can be a long term solution, but it is more costly than Option 3 resizing canals.

\section{Recommendations}

Flood problem is effected by human behaviour therefore social participatory should be included which can be done by forming community care of flood, socialization and training, and rising mutual cooperation known as "Gotong Royong". Social participatory is needed to improve society's awareness, their belonging and responsibility to keep the rivers and drainage canals clean and to maintain thepublic hydraulic infrastructures operate well.

Government also should prepare a good spatial planning and control the land use change caused by development because land use change during development will increase the paved area so the amount of rainfall that can infiltrate into ground becomes smaller, and the surface runoff will be bigger.

It is also necessary to analyze and evaluate cost of each option in order to support a good decision making to improve drainage performance in Gedongtataan. 


\section{Acknowledgement}

My deepest thanks to all my supervisors Prof. Dr. Charlotte de Fraiture, M.Sc (UNESCO-IHE, Delft, the Netherlands), Prof. Dr. Ir. Robiyanto H. Susanto, M.Agr.Sc (Sriwijaya University, Palembang, Indonesia), and Dr. F.X. Suryadi, M.Sc (UNESCO-IHE, Delft, the Netherlands) for their patient guidance and supervision. I thank you to my mother, my sisters, my brothers, and my big families for your support.

\section{References}

[1] Badilla, R. A, 2008. Flood Modelling in Pasig-Marikina River Basin. International Institute For Geo-Information Science and Earth Observation. ITC, Enschede, Netherlands.

[2] BBWS Mesuji Sekampung, 2015. Data Curah Hujan (Rainfall Data) 2002-2006, 2009-2014. Bandar Lampung.

[3] Booth, D. B, 1991. Urbanization and the natural drainage system - impacts, solutions, and prognoses. The Northwest Environmental Journal 7(1991), pp. 93 - 118

[4] Butler, D., J. Davies, 2004. Urban Drainage .Spon Press. London.

[5] Clemmens et al., 1993. Description and evaluation of program: Duflow. Journal of Irrigation and Drainage Engineering 4(724), doi:10.1061.

[6] Indonesia Ministry of Public Works and Housings, 2003. Panduan dan Petunjuk Praktis Pengelolaan Drainase Perkotaan. Jakarta.

[7] Konrad, C., 2003. Effects of Urban Development on Floods. U.S. Geological Survey, U.S. Department of the Interior. [terhubung berkala]. http://pubs.usgs.gov/fs/fs07603/
[8] Madamombe, C. E., 2010. Water source allocation and numerical water quality modelling in roxo reservoir catchment, portugal. Enschede, The Netherlands: International Institute for Geo-Information Science and Earth Observation. [terhubung berkala] https://www.itc.nl/library/papers_2010/msc/wrem/madamo mbe.pdf

[9] Meteorology, Climatology, and Geophysics Agency of Tegineneng. 2015. Data Hujan Harian for period 20022014. Bandar Lampung.

[10] Ningsih, 2014. Urban Drainage Management System in Sport and Ecotourism Centre of Jakabaring, Palembang City, South Sumatra, Indonesia. UNESCO-IHE, Netherlands.

[11] Patra, K. C., 2008. Hydrology and Water Resources Engineering (second ed.). Alpha Science International Ltd Oxford, U.K.

[12] Ponce, V. M., 1989. Q\&A on the return period to be used for design year. [terhubung berkala]. http://www/returnperiod.sdsu.edu. [31 Oktober 2015].

[13] Statistics Board of Pesawaran Regency. 2014. Pesawaran Dalam Angka 2013. Gedongtataan, Lampung

[14] STOWA, Systems, M., 2004. Duflow Manual. Leidchendam EDS and IHE Delft, Netherlands.

[15] Suripin, 2004. Sistem Drainase Perkotaan yang Berkelanjutan. ANDI, Yogyakarta

[16] Triatmodjo, B., 2008. Hidrologi Terapan (second ed.). Beta Offset, Yogyakarta.

[17] Urban Development Planning Board of Pesawaran Regency, 2013. Masterplan Drainase Kabupaten Pesawaran. Gedongtataan.

[18] Yuksek et al., 2013. Assessment of big floods in the Eastern Black Sea Basin of Turkey. Environ Monit Assess 185, pp. $797-814$. 